\title{
Novel algal symbiont (Symbiodinium spp.) diversity in reef corals of Western Australia
}

\author{
Rachel N. Silverstein ${ }^{1,4,}$, Adrienne M. S. Correa ${ }^{1,5}$, Todd C. LaJeunesse ${ }^{2}$, \\ Andrew C. Baker ${ }^{1,3,4}$
}

${ }^{1}$ Department of Ecology, Evolution and Environmental Biology, Columbia University, MC 5557, 1200 Amsterdam Avenue, New York, New York 10027, USA

${ }^{2}$ Department of Biology, The Pennsylvania State University, 221 Mueller Laboratory, University Park, Pennsylvania 16802, USA

${ }^{3}$ Wildlife Conservation Society, International Conservation - Marine Program, 2300 Southern Boulevard, Bronx, New York 10460, USA

${ }^{4}$ Present address: Division of Marine Biology and Fisheries, Rosenstiel School of Marine and Atmospheric Science, University of Miami, 4600 Rickenbacker Causeway, Miami, Florida 33149, USA

${ }^{5}$ Present address: Department of Biological Sciences, Florida International University, 3000 NE 151st St., North Miami, Florida 33181, USA

\begin{abstract}
The identity and diversity of algal symbionts (Symbiodinium spp.) in reef corals is thought to influence to the resilience of reef ecosystems to climate change, and varies depending on coral species, environmental conditions, and biogeography. We examined these factors by surveying corals along a latitudinal gradient in Western Australia on reefs connected north to south by the warm-water Leeuwin Current. We used the internal transcribed spacer-2 (ITS-2) region of ribosomal DNA to characterize Symbiodinium communities in 19 species of reef coral (in 16 genera) from tropical Dampier $\left(20.5^{\circ} \mathrm{S}\right)$ to temperate Dunsborough $\left(33.5^{\circ} \mathrm{S}\right)$. We documented a high number of novel ITS-2 types in Symbiodinium clades B (1 type) and C (14 types) as well as 7 previously reported ITS2 types in clades B, C, and D. In addition, we compared symbiont distributions with Giovanni's OBIG MODIS-Aqua satellite temperature data set and found that the putatively thermotolerant Symbiodinium ITS-2 type D1a was more frequently detected in 'chronically warm' tropical sites than at 'chronically cool' temperate sites, while clade B symbiont types showed the reverse pattern, being found in certain corals at the southernmost sites. Symbiodinium type D1a was generally most abundant at Dampier, where bleaching had occurred 1 mo prior to sampling, although some variation by host taxa was observed. The diverse and novel Symbiodinium communities documented here may be a result of (1) the variable environmental histories of the study sites, (2) the apparent genetic divergence within this genus resulting from the relative isolation of Western Australian reefs, and/or (3) the frequent transport of symbionts (in hospite or free-living) from Indo-Malay reefs to Western Australia via the Leeuwin Current. These results indicate that understudied reefs in remote and isolated areas may contain Symbiodinium diversity that has not been reported previously.
\end{abstract}

KEY WORDS: Corals · Scleractinia · Denaturing gradient gel electrophoresis · DGGE · Internal transcribed spacer-2 region · ITS-2 $\cdot$ Latitudinal gradient $\cdot$ Symbiodinium $\cdot$ Western Australia $\cdot$ Reefs

Resale or republication not permitted without written consent of the publisher

\section{INTRODUCTION}

Symbiotic associations between corals and dinoflagellate algae (genus Symbiodinium) underpin the high levels of productivity characterizing coral reefs (Muscatine \& Porter 1977). However, when exposed to stressful environmental conditions, coral-algal symbioses can break down, resulting in 'bleaching' (the loss of algal cells and/or pigments; reviewed in Glynn 1996). If bleaching is prolonged or severe, colony mortality can result (Brown 1997, Goldberg \& Wilkinson 2004). Biogeographic patterns in coral distribution cor- 
relate with prevailing temperature regimes, indicating that this environmental factor strongly influences coral-algal mutualisms (Veron 1995) and their susceptibility to bleaching (Coles et al. 1976). In addition, high sea-surface temperatures (SSTs) have been implicated in all episodes of mass bleaching documented to date (Glynn 1996, Baker et al. 2008). Given that climate change is expected to increase the severity and frequency of thermal anomalies in the coming decades (Hoegh-Guldberg 1999, Hughes et al. 2003, Donner et al. 2005), there is considerable uncertainty regarding the capacity of corals to adapt or acclimatize at pace with projected rates of climate change (e.g. HoeghGuldberg et al. 2007), and the potential role(s) of algal symbiont diversity in this process (e.g. Baker et al. 2004, Berkelmans \& van Oppen 2006, Sampayo et al. 2008, Correa \& Baker 2011).

Scleractinian corals typically associate with Symbiodinium in 4 sub-generic clades, A, B, C, and D (reviewed in Baker 2003), while symbionts in clades $F$ and $\mathrm{G}$ are only rarely harbored by stony corals (Rodriguez-Lanetty et al. 2004, LaJeunesse et al. 2010a). Numerous sub-clade 'types' have also been identified within each Symbiodinium clade, most frequently using the internal transcribed spacer-2 (ITS-2) region of a multi-copy ribosomal DNA (rDNA) gene family (e.g. LaJeunesse 2002). Studies have shown that functional traits can differ among symbiont types both in hospite and in culture, particularly with respect to their temperature optima (Iglesias-Prieto et al. 1992, Warner et al. 1999, Sampayo et al. 2008; Thornhill et al. 2008, Hennige et al. 2009), response to thermal stress, and influence on the relative bleaching susceptibility/ resistance of their scleractinian hosts (Rowan et al. 1997, Glynn et al. 2001, Rowan 2004, Goulet et al. 2005, Berkelmans \& van Oppen 2006, Jones et al. 2008, LaJeunesse et al. 2010b).

Coral species vary in the potential and realized diversity of symbionts that they associate with. In a given coral host, local environmental conditions (e.g. temperature, irradiance), symbiont availability, biogeography, and/or stress history (reviewed in Baker 2003) can all influence which Symbiodinium taxa numerically dominate a colony. Corals living at latitudinal extremes are particularly interesting in this respect, because they experience intense seasonal environmental changes which may promote diverse symbiont communities. Western Australian reefs span transitional (tropical to temperate) reef coral environments, and are further extended into high latitudes by the warm-water Leeuwin Current (an offshoot of the Indonesian Throughflow), allowing coral colonies to survive in areas where low temperature might otherwise be prohibitive (Cresswell 1991, Caputi et al. 1996, Wijffels et al. 1996). Scleractinian coral generic and species richness decreases with latitude from 57 genera (216 species) at Dampier, to 4 genera $(7$ species) at Dunsborough (Veron \& Marsh 1988, our Table 1). A latitudinal sampling strategy is therefore more likely to capture important intermediate or high Symbiodinium diversity zones along Australia's western coast (if they exist). Surveys of coral-algal symbioses from Western Australia can also be compared with similar latitudinal comparisons from other geographic regions (e.g. Baker 1999, Loh et al. 2001, Rodriguez-Lanetty et al. 2001, van Oppen et al. 2001, 2005, Savage et al. 2002, Macdonald et al. 2008, LaJeunesse et al. 2010a) to corroborate hypothesized biogeographic patterns in the distribution of Symbiodinium diversity, and to determine where exceptions to these patterns arise, and why.

\section{MATERIALS AND METHODS}

Field methods. Mixed samples of coral tissue, skeleton, and resident symbiont communities were collected from 19 species of scleractinian coral host (in 16 genera) during the austral winter season between 30 May and 11 June 2005 (with the exception of the Houtman-Abrolhos Islands, which were sampled in July 2005) at 5 locations along the coast of Western Australia. Sampled locations were tropical (Dampier:

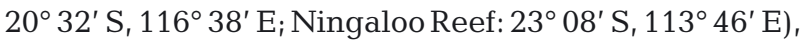
or temperate (Abrolhos Islands: $28^{\circ} 16^{\prime} \mathrm{S}, 113^{\circ} 35^{\prime} \mathrm{E}_{\text {; }}$ Rottnest Island: $32^{\circ} 00^{\prime} \mathrm{S}, 115^{\circ} 31^{\prime} \mathrm{E}$; Dunsborough: $33^{\circ} 36^{\prime} \mathrm{S}, 115^{\circ} 05^{\prime} \mathrm{E}$ ) (see Fig. 3, Table 1). Average monthly SSTs for each site between July 2002 and June 2005 were obtained from the GES-DISC Interactive Online Visualization ANd aNalysis Infrastructure (Giovanni; http://disc.sci.gsfc.nasa.gov/giovanni), which is part of NASA's Goddard Earth Sciences (GES) Data and Information Services Center (DISC). The averages for each month were then averaged between the same month for 2002, 2003, 2004 and 2005. Average yearly temperature ranges as well as average temperatures for the months immediately prior to sampling (March through June 2005) are reported in Table 1. Specifically, SSTs were acquired from Giovanni's OBIG MODIS-Aqua Monthly Global standard mapping images (9 km resolution), through the Ocean Biology Processing Group. Although the temperatures reported here represent those at the sea surface rather than at the depth of sampling, satellite-derived SSTs are common proxies for temperatures experienced by corals at relatively shallow depths, and have been used to accurately predict bleaching events (e.g. Jokiel \& Coles 1990, Goreau \& Hayes 1994, Strong et al. 1997, Berkelmans 2002, McClanahan et al. 2007).

All sample collections were made using SCUBA at $<7 \mathrm{~m}$ depth, except in Dunsborough, where the maxi- 
Table 1. General information on study sites including geographic coordinates, number of scleractinian coral genera and species previously documented (Veron \& Marsh 1988), average (avg.) sea surface temperature (SST) (averaged from March to June 2005), average yearly SST range (monthly average SSTs, averaged over 2002-2005), and known bleaching history (from 2002 to 2005; www.reefbase.org)

\begin{tabular}{|lccccc|}
\hline Site & Coordinates & $\begin{array}{c}\text { No. of } \\
\text { genera } \\
\text { and spp. }\end{array}$ & $\begin{array}{c}\text { Avg. } \\
\text { SST } \\
\left({ }^{\circ} \mathrm{C}\right)\end{array}$ & $\begin{array}{c}\text { Avg. } \\
\text { SST } \\
\text { range }\left({ }^{\circ} \mathrm{C}\right)\end{array}$ & Bleaching \\
\hline Dampier & $20^{\circ} 32^{\prime} \mathrm{S}, 116^{\circ} 38^{\prime} \mathrm{E}$ & 57 and 216 & 30 & $24-30$ & Moderate \\
Ningaloo & $23^{\circ} 08^{\prime} \mathrm{S}, 113^{\circ} 46^{\prime} \mathrm{E}$ & 54 and 217 & 27 & $22-27$ & None \\
Abrolhos & $28^{\circ} 16^{\prime} \mathrm{S}, 113^{\circ} 35^{\prime} \mathrm{E}$ & 42 and 184 & 23 & $19-23$ & None \\
Rottnest & $32^{\circ} 00^{\prime} \mathrm{S}, 115^{\circ} 31^{\prime} \mathrm{E}$ & 16 and 25 & 22 & $18-22$ & None \\
Dunsborough & $33^{\circ} 36^{\prime} \mathrm{S}, 115^{\circ} 05^{\prime} \mathrm{E}$ & 4 and 7 & 21 & $17-21$ & None \\
\hline
\end{tabular}

was performed using a Big Dye Terminator v. 3.1 cycle sequencing kit and an Applied Biosystems 3730xl DNA Analyzer.

Sequences were assembled and edited using the Vector NTI ${ }^{\mathrm{TM}}$ Advance 10 software (Invitrogen) and then identified using BLAST searches of GenBank to determine the most similar known Symbiodinium type, cf. LaJeunesse (2001). To verify GenBank identifications, sequences were grouped according to clade, and aligned with a database of known Symbiodinium diversity for that clade using ClustalX version 2.0 (Thompson et al. 1997), as described in

mum collection depth was $15 \mathrm{~m}$. Samples were collected using a hammer and hollow steel punch $\left(<1 \mathrm{~cm}^{2}\right.$ diameter) penetrating the coral skeleton deeply enough to capture all tissue layers ( 3 to $6 \mathrm{~mm}$ deep). Samples were taken only from the tops of healthy colonies, including at Dampier, where moderate bleaching (11 to $30 \%$ of corals affected; www.reefbase. org) was reported approximately 1 mo prior to sampling (www.reefbase.org, D. Blakeway pers. comm.). Corals that were heavily shaded or overtopped by other colonies were not sampled, nor were colonies at Dampier that appeared to have experienced bleaching (i.e. showed signs of abnormal pigmentation) in June 2005. Colonies were identified based on the taxonomy of Veron (2000). To minimize the likelihood of repeatedly sampling corals that were the same genetic individual, only conspecifics separated by $>10 \mathrm{~m}$ were sampled. Collected tissue was preserved for DNA analysis in either $95 \%$ ethanol or saline DMSO buffer (20\% (v/v) DMSO, 250 mM EDTA, saturated $\mathrm{NaCl}$ ) (Seutin et al. 1991).

Molecular methods. DNA was extracted from each sample using an organic extraction protocol (Baker et al. 1997). The ITS-2 region was amplified from each sample using the Symbiodinium-specific primers 'ITSintfor2' and 'ITS2clamp' (LaJeunesse \& Trench $2000)$ with the following profile: an initial denaturing step of $94^{\circ} \mathrm{C}$ for $3 \mathrm{~min}$, followed by 35 cycles of $1 \mathrm{~min}$ at $94^{\circ} \mathrm{C}, 1 \mathrm{~min}$ at $58^{\circ} \mathrm{C}$, and $1 \mathrm{~min}$ at $74^{\circ} \mathrm{C}$, followed by a single cycle of $7 \mathrm{~min}$ at $74^{\circ} \mathrm{C}$. Products were electrophoresced on $1.2 \%$ agarose gels to check for amplification success. Symbiodinium amplicons were then separated using denaturing gradient gel electrophoresis (DGGE, 35 to $75 \%$ gradient; Sunnucks et al. 2000) on a CBS Scientific system. Prominent bands characteristic of unique profiles (as described by LaJeunesse 2002) were excised, bead-beaten, and re-amplified using the same primer set (without the GC clamp) under the conditions described above. Sequencing
Correa \& Baker (2009). Pairwise alignment parameters included a gap opening of 10.00 and a gap extension of 0.10. Multiple alignment parameters included a gap opening of 15.00 and a gap extension of 0.30 (Hall 2001). Clade-level alignments were corrected manually and trimmed to the length of the shortest sequence. Final alignments (including gaps) for Symbiodinium clades B, C, and D were 322,340 , and 246 base pairs long, respectively. TCS version 1.21 (Clement et al. 2000) was then used to group identical sequences within each cladelevel alignment and to produce statistical parsimony networks with $95 \%$ certainty. Gaps were treated as a fifth character state. Sequences within the same TCS-defined 'haplotype' were all scored as the same Symbiodinium type; each 'haplotype' took the name of the lowest alphanumeric Symbiodinium type (cf. LaJeunesse 2001) that it contained.

GenBank and TCS-derived identifications of sequenced samples were further checked through comparisons of their DGGE banding patterns with those of Symbiodinium ITS-2 types in the published literature. Finally, the Symbiodinium ITS-2 types within nonsequenced samples were identified by matching their DGGE banding patterns to those of sequenced samples on the same gel. All sequences deemed 'novel' had a distinct and reproducible DGGE banding pattern with a clearly dominant band and associated minor banding fingerprint.

Statistical analyses. Average monthly temperatures (and their standard deviations) were calculated for each site based on temperature data for 2002 to 2005 downloaded from the Giovanni online data system. Since these data passed normality and equal-variance tests, a 1-way ANOVA was used to determine whether sites differed in their average monthly temperatures, using SigmaStat 3.0 (www.spss.com). The Holm-Sidak method was used to perform multiple pairwise comparisons.

The abundance of Symbiodinium in clade D was compared (within a given host species) between sites 
and latitudes using Fisher's exact tests. These comparisons involved either (1) specific host species between individual sites, (2) multiple host species in sites that were collectively 'chronically warm' (Dampier and Ningaloo Reef; mean temperature range: 27 to $30^{\circ} \mathrm{C}$ ) versus 'chronically cool' (Abrolhos Islands, Rottnest Island, and Dunsborough; mean temperature range: 21 to $23^{\circ} \mathrm{C}$ ) (see Fig. 4), or (3) multiple host species in sites with different bleaching histories.

Since few of these host taxa were observed at multiple sites, analyses of the distribution of clade D necessitated comparisons of different host taxa (from different sites). A caveat of this approach is that it assumes that all host taxa associate with Symbiodinium in clade D with equal facility. To help correct for this, Fisher's exact tests were therefore conducted for each location using only coral species that were known to be capable of hosting clade D symbionts, based on detections from conspecifics in the present study and (as reviewed in Baker \& Romanski 2007) Baker (1999), Fabricius et al. (2004), Chen et al. (2005), Visram \& Douglas (2006), Mostafavi et al. (2007), and Abrego et al. (2009). To be conservative, only clade D detections based on conventional molecular techniques were considered for these comparisons; real-time PCR detections were excluded. Coral species included in these tests were therefore Acropora latistella, Echinopora lamellosa, Favites abdita, Galaxea fascicularis, Goniastrea aspera, Goniastrea australiensis, Hydnophora rigida, Lobophyllia hemprichii, Pocillopora damicornis, Stylophora pistillata, Turbinaria mesenterina, and T. reniformis.

\section{RESULTS}

\section{DGGE banding patterns}

Many of the DGGE banding patterns produced by Western Australian coral samples were complex (i.e. contained many minor bands), particularly within clade C (Fig. 1a-c). From such samples, numerous bands were excised in order to determine the number of types present, and which bands were intragenomic variants, heteroduplexes, or non-target amplifications (i.e. host sequence). Complex profiles were especially common for Symbiodinium ITS-2 type C1 and co-dominant paralogs (i.e. C1c-ff, C1gg, C1gg-hh). Frequently, bands within $\mathrm{C} 1$ profiles were sequenced and were found to have associated band sequences that differed by a few base pairs. To capture the full breadth of sequence variation present in this region, therefore, these sequences were submitted to GenBank and differentiated by lower case letters (denoting co-dominant paralogs) according to LaJeunesse (2002) (our Table 3).

\section{Symbiodinium diversity and distribution}

\author{
Distribution of Symbiodinium ITS-2 types in \\ Western Australia
}

Of the 174 samples analyzed, 24 distinct Symbiodinium ITS-2 types were identified from clades B, C, and D within 19 different coral species, representing 16 genera (Table 2). Sixteen novel Symbiodinium ITS-2 types ( 1 in clade B and 14 in clade C) were identified based on their distinct DGGE banding profiles and sequences, including 1 variant profile representing D1a (Fig. 1, Table 3). Of these novel sequences, Symbiodinium ITS-2 types C124 and C128 appear most divergent: they could not be connected to the statistical parsimony network with 95\% certainty (Fig. 2b), although $\mathrm{C} 124$ could be connected with $93 \%$ certainty (with $93 \%$ certainty, this type was 8 base-pair changes from both the C3 and C1ff types; data not shown). Novel types C125 and C126 harbored by Pocillopora damicornis colonies appear to be closely related to one another, yet are highly divergent from the ancestral C1 type and most other known types. Novel types C123 and $\mathrm{C} 127$ also differ from other C-types by at least 5 fixed base-pair changes each (Fig. 2b). In the clade B statistical parsimony network, B40 could not be connected to other known types with $95 \%$ statistical support (Fig. 2a), nor with as low as $90 \%$ statistical support (data not shown). In a separate maximum parsimony clade $B$ tree generated from a similar sequence data set, type B40 was also placed in its own branch (data not shown).

The most frequently detected algal types in all of the coral communities sampled were in Symbiodinium clade C (Fig. 3, Table 2). ITS-2 variants of type $\mathrm{C} 1$ (i.e. $\mathrm{C} 1$ and accompanying diagnostic paralogs) were found in $50 \%$ of all samples from the region, when all host species are considered ( $\mathrm{n}=87$ of 174; Fig. 3, Table 2). Symbiodinium ITS-2 types B18 and B40 were restricted to temperate regions (Rottnest Island and Dunsborough; $\mathrm{n}=17$ of 63 colonies, $26.7 \%$; Fig. 3, Table 2), and were mainly hosted by corals observed only at these temperate sites: B40 associated with Coscinaraea marshae, C. mcneilli, and B18 associated with Plesiastrea versipora (Table 2). While B18 has been documented previously (A. C. Baker \& T. C. LaJeunesse unpubl. data; GenBank accession number: AY258471.1), the present study is the first published report in which it appears. ITS-2 type D1a was the only clade D symbiont detected from Western Australian reefs, although an unusual variant D1a profile was detected from 1 colony of Pocillopora damicornis from Dampier (Fig. 1d). D1a was primarily found in the tropics, at Dampier and Ningaloo Reef, and most commonly in Galaxea fasci- 
cularis, Favites abdita, and Goniastrea aspera (Table 2).

The present paper represents the first report of Symbiodinium type C7 from the Indo-Pacific; however, sequence analysis of the hyper-variable non-coding region of the chloroplast $p s b A$ minicircle indicates that this may be due to homoplasy, with the C7 in Western Australia having a distinct evolutionary history from the Caribbean C7 (data not shown). ITS-2 types C7 and C7d were only identified in Dunsborough, suggesting that these may be low-temperature or low-irradiance specialists, although several of the host species from which these types were identified were only encountered during sampling in Dunsborough (Coscinarea mcneilli [ $\mathrm{n}=1]$ and Turbinaria reniformis $[\mathrm{n}=2$ ]; Fig. 3, Table 2). However, Symphillia wilsoni hosted C7 at Dunsborough $(\mathrm{n}=3)$ but contained the novel C type C1gg at Rottnest Island $(\mathrm{n}=4)$ (Fig. 3, Table 2), supporting the notion that $\mathrm{C} 7$ and its variant $\mathrm{C} 7 \mathrm{~b}$ may be optimal in lower-latitude environments.

Similar to Symphillia wilsoni, Pocillopora damicornis also hosted different clade $\mathrm{C}$ symbionts at different sites. In northern locations (Dampier and the Ningaloo Reef), sampled colonies hosted $\mathrm{C} 1 \mathrm{~h}(\mathrm{n}=25)$, while only novel C-types were observed at the more southerly Abrolhos and Rottnest Islands (Abrolhos Islands: C125 [n = 2], C126 [n = 5]; Rottnest Island: C1c-ff [n = 11]; Table 2).

Fig. 1. Negative images of denaturing gradient gel electrophoresis (DGGE) profiles for the Symbiodinium internal transcribed spacer-2 (ITS-2) types collected in Western Australia. Alphanumeric designation for each symbiont type is given above the corresponding fingerprint profile: uppercase letters indicate clade, numbers represent ITS-2 type, and lowercase letters (if present) denote the presence of an rDNA para$\log$ (i.e. co-dominant intragenomic variants that are a diagnostic part of the fingerprint). *: Types that are novel (i.e. previously unreported). Representative banding patterns for detected $S y m$ biodinium types in $(\mathrm{a}-\mathrm{c})$ clade $\mathrm{C}$ and $(\mathrm{d})$ clades $\mathrm{B}$ and D. Open arrowheads indicate bands that sequenced as coral host. Solid arrowheads indicate known ITS2 type marker sequences. The white star denotes an unusual D1a banding pattern identified in 1 sample of Pocillopora damicornis from Dampier

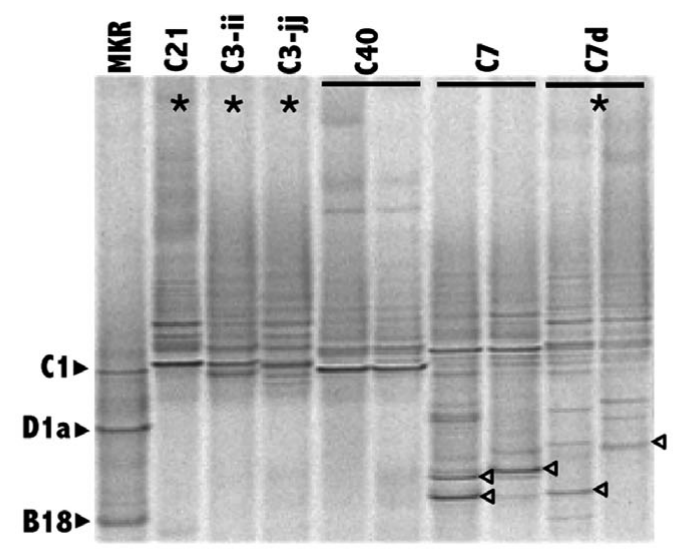

a

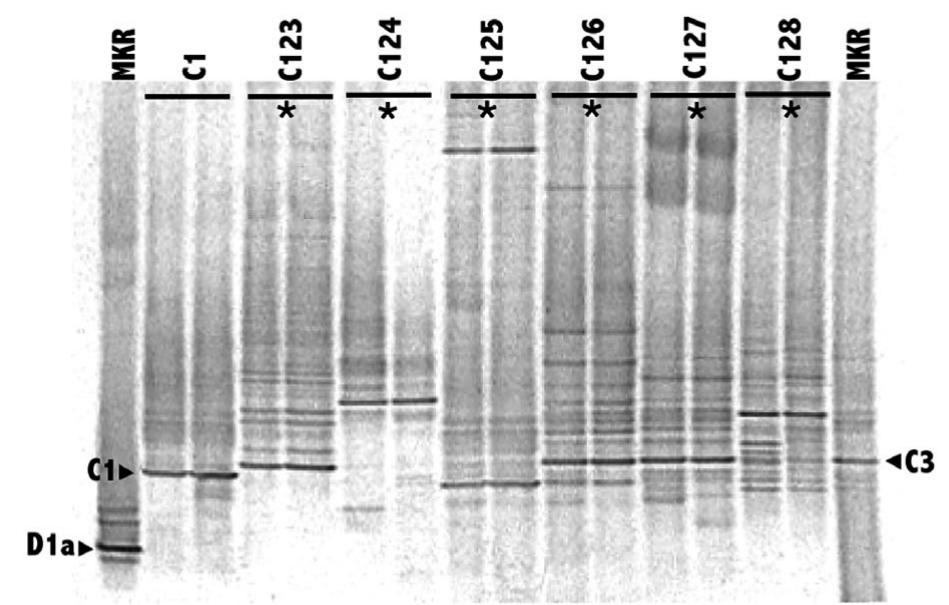

b
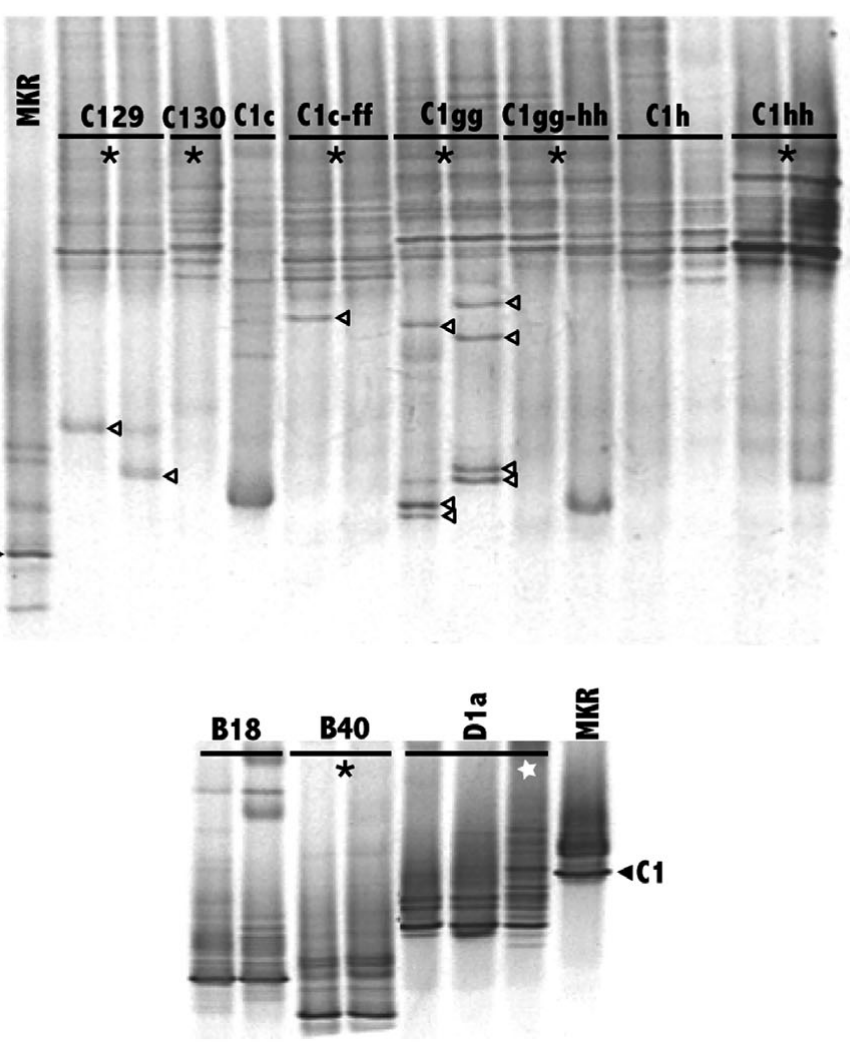

d 
Table 2. Site, coral host species, and Symbiodinium identity for samples collected from Western Australia, as well as the number of times a particular coral-Symbiodinium combination was observed. ${ }^{*}$ Coral species from which algal symbionts have not previously been identified, or coral-Symbiodinium combinations that have not been reported previously (based on Visram \& Douglas 2006 and data in Baker \& Romanski 2007)

\begin{tabular}{|c|c|c|c|c|}
\hline \multirow{2}{*}{$\begin{array}{l}\text { Site (no. colonies } \\
\text { sampled site }{ }^{-1} \text { ) }\end{array}$} & \multirow[t]{2}{*}{ Coral species } & \multicolumn{2}{|c|}{ Symbiodinium } & \multirow{2}{*}{$\begin{array}{c}\text { No. } \\
\text { observed }\end{array}$} \\
\hline & & Clade & ITS-2 type & \\
\hline \multirow{9}{*}{$\begin{array}{l}\text { Dampier } \\
(\mathrm{n}=27)\end{array}$} & \multirow[t]{3}{*}{ Acropora latistella } & $\mathrm{C}$ & C3ii & 1 \\
\hline & & $\mathrm{C}$ & $\mathrm{C} 40$ & 2 \\
\hline & & $\mathrm{C}+\mathrm{D}$ & $\mathrm{C} 40+\mathrm{D} 1 \mathrm{a}$ & 1 \\
\hline & Favites abdita & $\mathrm{D}$ & D1a & 5 \\
\hline & \multirow{2}{*}{ Goniastrea aspera } & $\mathrm{C}$ & $\mathrm{C} 1 \mathrm{c}$ & 1 \\
\hline & & $\mathrm{D}$ & D1a & 6 \\
\hline & Goniastrea australiensis & $\mathrm{D}$ & D1a & 1 \\
\hline & \multirow{2}{*}{ Pocillopora damicornis } & $\mathrm{C}$ & C1h & 9 \\
\hline & & $\mathrm{D}$ & D1a & 1 \\
\hline \multirow{13}{*}{$\begin{array}{l}\text { Ningaloo Reef } \\
(\mathrm{n}=61)\end{array}$} & Cyphastrea chalcidicum & $\mathrm{C}$ & $\mathrm{C} 40$ & 2 \\
\hline & \multirow{2}{*}{ Echinopora lamellosa } & $\mathrm{C}$ & C21 & 1 \\
\hline & & $\mathrm{C}$ & $\mathrm{C} 40$ & 7 \\
\hline & \multirow[t]{3}{*}{ Galaxea fascicularis } & $\mathrm{C}$ & $\mathrm{C} 40$ & 3 \\
\hline & & $\mathrm{C}+\mathrm{D}$ & $\mathrm{C} 1+\mathrm{D} 1 \mathrm{a}$ & 1 \\
\hline & & $\mathrm{C}+\mathrm{D}$ & $\mathrm{C} 40+\mathrm{D} 1 \mathrm{a}$ & 2 \\
\hline & Hydnophora rigida & $\mathrm{C}$ & $\mathrm{C} 40$ & 2 \\
\hline & Lobophyllia hemprichii & $\mathrm{C}$ & $\mathrm{C} 40$ & 3 \\
\hline & Pocillopora damicornis & $\mathrm{C}$ & C1h & 16 \\
\hline & Seriatopora caliendrum* & $\mathrm{C}$ & C123 & 7 \\
\hline & Stylophora pistillata & $\mathrm{C}$ & C1 & 15 \\
\hline & Turbinaria mesenterina & $\mathrm{C}$ & $\mathrm{C} 130$ & 1 \\
\hline & & $\mathrm{C}$ & C3jj & 1 \\
\hline \multirow{6}{*}{$\begin{array}{l}\text { Abrolhos Islands } \\
(\mathrm{n}=23)\end{array}$} & \multirow[t]{2}{*}{ Favites abdita } & $\mathrm{C}$ & C1 & 5 \\
\hline & & $\mathrm{C}$ & C129 & 2 \\
\hline & Goniastrea aspera & $\mathrm{C}$ & C1gg-hh & 6 \\
\hline & Goniastrea australiensis & $\mathrm{C}$ & C1gg & 3 \\
\hline & \multirow[t]{2}{*}{ Pocillopora damicornis } & $\mathrm{C}$ & $\mathrm{C} 125$ & 2 \\
\hline & & $\mathrm{C}$ & C126 & 5 \\
\hline \multirow{6}{*}{$\begin{array}{l}\text { Rottnest Island } \\
(\mathrm{n}=45)\end{array}$} & Coscinaraea marshae* & $\mathrm{B}$ & B40 & 9 \\
\hline & Goniastrea australiensis & $\mathrm{C}$ & C1gg & 13 \\
\hline & \multirow[t]{2}{*}{ Montipora mollis } & $\mathrm{C}$ & C124 & 4 \\
\hline & & $\mathrm{C}$ & C128 & 2 \\
\hline & Plesiastrea versipora & B & B18 & 2 \\
\hline & Pocillopora damicornis & $\mathrm{C}$ & C1c-ff & 11 \\
\hline \multirow{7}{*}{$\begin{array}{l}\text { Dunsborough } \\
(\mathrm{n}=18)\end{array}$} & \multirow[t]{2}{*}{ Coscinaraea mcneilli* } & $\mathrm{C}$ & $\mathrm{C} 7 \mathrm{~d}$ & 1 \\
\hline & & B & B18 & 1 \\
\hline & Goniastrea australiensis & $\mathrm{C}$ & C1ii & 4 \\
\hline & Plesiastrea versipora & B & B18 & 5 \\
\hline & Symphyllia wilsoni* & $\mathrm{C}$ & $\mathrm{C} 7$ & 3 \\
\hline & Turbinaria mesenterina & $\mathrm{C}$ & $\mathrm{C} 127$ & 2 \\
\hline & Turbinaria reniformis & $\mathrm{C}$ & $\mathrm{C} 7 \mathrm{~d}$ & 2 \\
\hline Grand total & & & & 174 \\
\hline
\end{tabular}

Temperature and the distribution of Symbiodinium ITS-2 types

Average monthly temperatures from 2002 to 2005 were significantly different between all sites, except for Rottnest Island, which was not significantly different from the Abrolhos Islands or Dunsborough $(\mathrm{df}=4$, $\mathrm{p}<0.001$ for all site comparisons except the Abrolhos Islands vs. Dunsborough, where p $<0.05$; Fig. 4). Based on average monthly temperatures from 2002 to 2005 and the results of the 1way ANOVA, for subsequent statistical analyses, Dampier and Ningaloo were designated as 'chronically warm' sites, while the Abrolhos Islands, Rottnest Island, and Dunsborough were classified as 'chronically cool' (Fig. 4).

Within the coral taxa known to host Symbiodinium in clade D, ITS-2 type D1a was collectively identified more frequently in the 'chronically warm' sites (Dampier and Ningaloo; $\mathrm{n}=17$ of 83, 20.4\%) than in the 'chronically cool' sites (Abrolhos Islands, Rottnest Island, Dunsborough; $\mathrm{n}=0$ of $55,0 \%$; Fisher's exact test: $p<0.0001$ ), as respective groups. Moreover, mean SSTs were significantly higher at Dampier (where bleaching was reported 1 mo prior to sampling) than at the other 'chronically warm' site, Ningaloo (Fig. 4) (1-way ANOVA, df = $4, \mathrm{p}<0.001)$. Symbiodinium ITS-2 type D1a was also detected more commonly at Dampier (also within coral taxa known to be capable of hosting Symbiodinium in clade $\mathrm{D}_{i} \mathrm{n}=14$ of 27 , $51.8 \%$ ), than at Ningaloo Reef ( $\mathrm{n}=3$ of 52, $5.7 \%$; Fisher's exact test: p < 0.0001) or the Abrolhos Islands, a chronically cool site ( $\mathrm{n}=0$ of $23,0 \%$; Fisher's exact test: $\mathrm{p}<0.0001$ ).

However, overall patterns in the distribution of type D1a varied between coral host species. For example, significantly more Goniastrea aspera colonies in Dampier hosted clade D ( $\mathrm{n}=6$ of 7 colonies, $86 \%$ ), than did conspecifics in the Abrolhos Islands $(\mathrm{n}=0$ of 6 colonies, $0 \%$; Fisher's exact test: $\mathrm{p}<0.01)$. Similarly, Favites abdita hosted more clade D Symbiodinium in Dampier ( $\mathrm{n}=5$ of 5 colonies, 100\%) than in the Abrolhos Islands ( $\mathrm{n}=0$ of 7 colonies, $0 \%$; Fisher's exact test: p < 0.01). In contrast, in Pocillopora damicornis colonies, Symbiodinium ITS-2 type D1a abundance was low at Dampier ( $\mathrm{n}=1$ of $10,10 \%$ ), Ningaloo Reef ( $\mathrm{n}=0$ of 16 , $0 \%$, and the Abrolhos Islands ( $\mathrm{n}=0$ of $7,0 \%$; no significant differences between pairwise comparisons by Fisher's exact test). Symbiodinium D1a was also observed within colonies of Turbinaria mesenterina and Goniastrea australiensis at multiple sites, but statistical comparisons could not be performed for these 


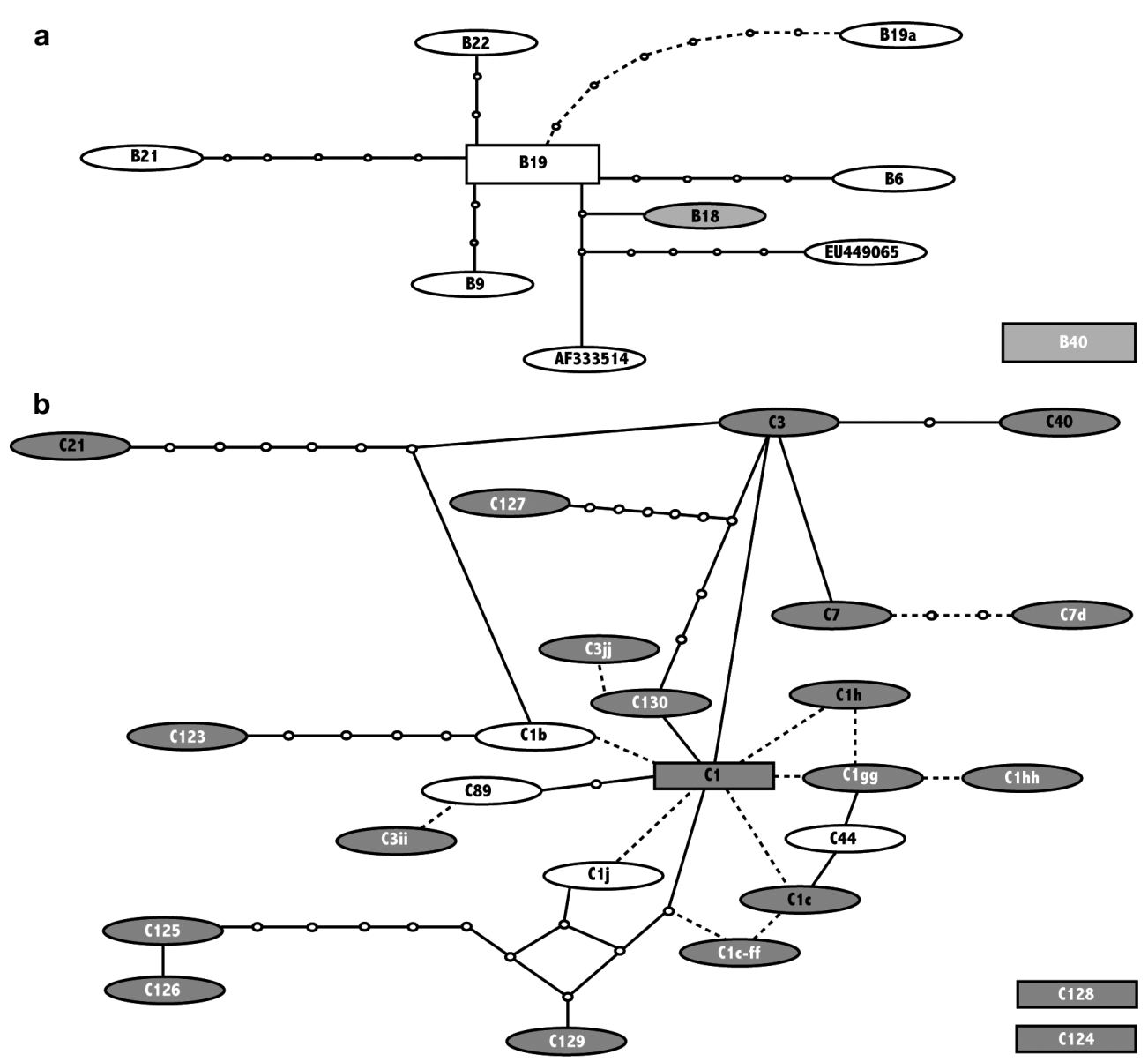

Fig. 2. Statistical parsimony networks depicting the novel Symbiodinium (a) clade B and (b) clade C internal transcribed spacer-2 (ITS-2) types identified in the present study and their relationships to related, previously described types, cf. LaJeunesse (2001). The estimated root for each network is represented by a rectangle. Lines represent single base-pair changes, while the dots between some lines represent hypothetical intermediate sequences. Dashed lines depict potential paralogs. Types with shaded backgrounds represent types identified in the present study, while types with white backgrounds represent ancestral or closely related types to those identified in this study. Types written in white letters denote novel (i.e. previously unreported) Symbiodinium types recovered in the present study

hosts due to the low number of colonies sampled at some sites.

Members of clade B, analyzed using all coral species, were found only at higher latitudes and appear restricted to temperate locations (Rottnest Island and Dunsborough; 17 of 63 colonies, $27 \%$ ).

\section{DISCUSSION}

\section{Symbiodinium ITS-2 diversity and novel types in Western Australia}

Despite a relatively limited sampling effort, a high diversity of Symbiodinium ITS-2 types, including various novel (i.e. previously unreported) types, were detected in reef corals from sites along the coast of
Western Australia (Figs. 1 \& 3, Tables 2 \& 3). Although some Symbiodinium ITS-2 types are common to Western Australia, eastern Australia (LaJeunesse et al. 2004a), and the northeastern and western Indian Ocean (LaJeunesse et al. 2010a), overall Western Australia can be differentiated from other nearby reefs based on its Symbiodinium diversity.

What factors might have contributed to Symbiodinium ITS-2 diversity and the high frequency of previously unreported symbionts in Western Australia? We suggest that the warm-water Leeuwin Current, which influences the coastal waters of Western Australia (Cresswell \& Golding 1980, Legeckis \& Cresswell 1981, Maxwell \& Cresswell 1981, Caputi et al. 1996) from the surface to 150-300 m depth (Thompson 1987), may help to supply Western Australian reefs with symbionts that are commonly found in tropical waters fur- 
Table 3. Novel Symbiodinium internal transcribed spacer-2 (ITS-2) types identified in the present study

\begin{tabular}{|lc|}
\hline Type cf. LaJeunesse (2001) & GenBank accession no. \\
\hline C123 & EU099826 \\
C124 & EU099827 \\
C125 126 & EU597011 \\
C126 127 & EU597012 \\
C128 & HQ328056 \\
C129 & EU099821 \\
C130 & HQ385805 \\
C1c-ff (the 'ff' band) & HQ385807 \\
C1gg (the 'gg' band) & HQ385810 \\
C1gg-hh (the 'hh' band) & HQ328057 \\
C3ii (the 'ii' band) & HQ328055 \\
C3jj (the 'jj' band) & HQ385806 \\
C7d (the 'd' band) & HQ385809 \\
B40 & EU099825 \\
\hline
\end{tabular}

ther north. This could occur via the dispersal of freeliving Symbiodinium, or the transport of coral larvae containing symbionts in hospite from the SE Asian Coral Triangle and the Timor Sea. The Leeuwin Current has previously been identified as being responsible for bringing tropical species (e.g. plankton, invertebrates, pollen) south of their expected principal distributions (i.e. the Indo-Malay region) to Australia's west coast as far as the Great Australian Bight (Blackburn 1942, Markina 1976, Marsh 1976, Maxwell \& Cresswell 1981, van der Kaars \& De Deckker 2003). It has also been identified as contributing to regions of biotic diversity that exhibit characteristics of both tropical and temperate areas (Markina 1976, Maxwell \& Cresswell 1981, Caputi et al. 1996).

Long-distance dispersal (e.g. 100s of km) of Symbiodinum by ocean currents has not been extensively studied. However, Howells et al. (2009) suggest that currents are the primary dispersal mechanism for Symbiodinium in horizontally transmitting coral species which do not pass Symbiodinium to their larvae (see also Magalon et al. 2006). Although ITS-2 Symbiodinium diversity has yet to be well described from the Indo-Malay region (but see Loh et al. 2001), we hypothesize that reefs in Western Australia are potentially 'sinks' for Indo-Malay Symbiodinium diversity. To test this hypothesis, a combination of phylogenetic and population genetic analyses of Symbiodinium (e.g. Santos et al. 2004, Magalon et al. 2006, Kirk et al. 2009, Pettay \& LaJeunesse 2009) in the same species of coral from the Indo-Malay region and Western Australia will be necessary to characterize symbiont population structure over this broad geographic area.

Adaptive radiations, particularly of the ancestral C1 type, could also be responsible for the high levels of
Symbiodinium diversity identified from Western Australia. Further investigations of the Symbiodinum diversity found in this region using multiple genetic markers (e.g. ITS-1, psbA mitochondrial minicircles, and microsatellite flanking regions) and high-sensitivity techniques, such as quantitative PCR, will better illustrate how evolutionarily disparate these Western Australian symbionts are from symbionts in other locations. Ultimately, the high diversity detected in this region may be the result of both the influx of tropical Symbiodinium types, and their subsequent isolation and divergence under the varied and changing environmental conditions found along this continent's coastline.

\section{Biogeographic and environmental patterns in Symbiodinium ITS-2 type diversity}

Symbiodinium ITS-2 diversity detected from Western Australian stony corals corroborated previously observed biogeographic and latitudinal patterns, while also increasing the total known diversity of coral-Symbiodinium associations and Symbiodinium ITS-2 types (Tables $2 \& 3$ ). The clade $\mathrm{C}$ dominance reported here agrees with the only other study of Symbiodinium from Western Australia: van Oppen et al. (2001) found only clade $\mathrm{C}$ symbionts in 3 Acropora species $(\mathrm{n}=10$ colonies total) from Ningaloo Reef in 1998 using single-stranded conformation polymorphism analysis of the ITS-1 region.

Our results also complement previous studies of Symbiodinium diversity at high latitudes (e.g. Rodriguez-Lanetty et al. 2001, Savage et al. 2002, Macdonald et al. 2008, Thornhill et al. 2008) and in isolated locations (e.g. LaJeunesse et al. 2004a) and studies done on the host species sampled in the present study throughout the Indo-Pacific (e.g. Loh et al. 2001, LaJeunesse et al. 2003, 2004b, 2008, 2010a, Chen et al. 2005, McClanahan et al. 2005). The symbiont type C1h harbored by most of the Pocillopora damicornis sampled in the present study, for example, was also the most common symbiont in these corals sampled from Zanzibar, Tanzania, in the Western Indian Ocean (LaJeunesse et al. 2010a), indicating that some of the partner combinations found in Western Australia occur in other regions of the Indian Ocean.

Furthermore, Baker (1999) and Rodriguez-Lanetty et al. (2001) conducted latitudinal surveys of Plesiastrea versipora along the eastern coast of Australia and documented that symbionts in clade C-dominated colonies in tropical areas, while Symbiodinium clade B associated with colonies from temperate waters. $P$. versipora and Coscinaraea marshae in the present study also harbored clade B representatives B18 and B40, respec- 

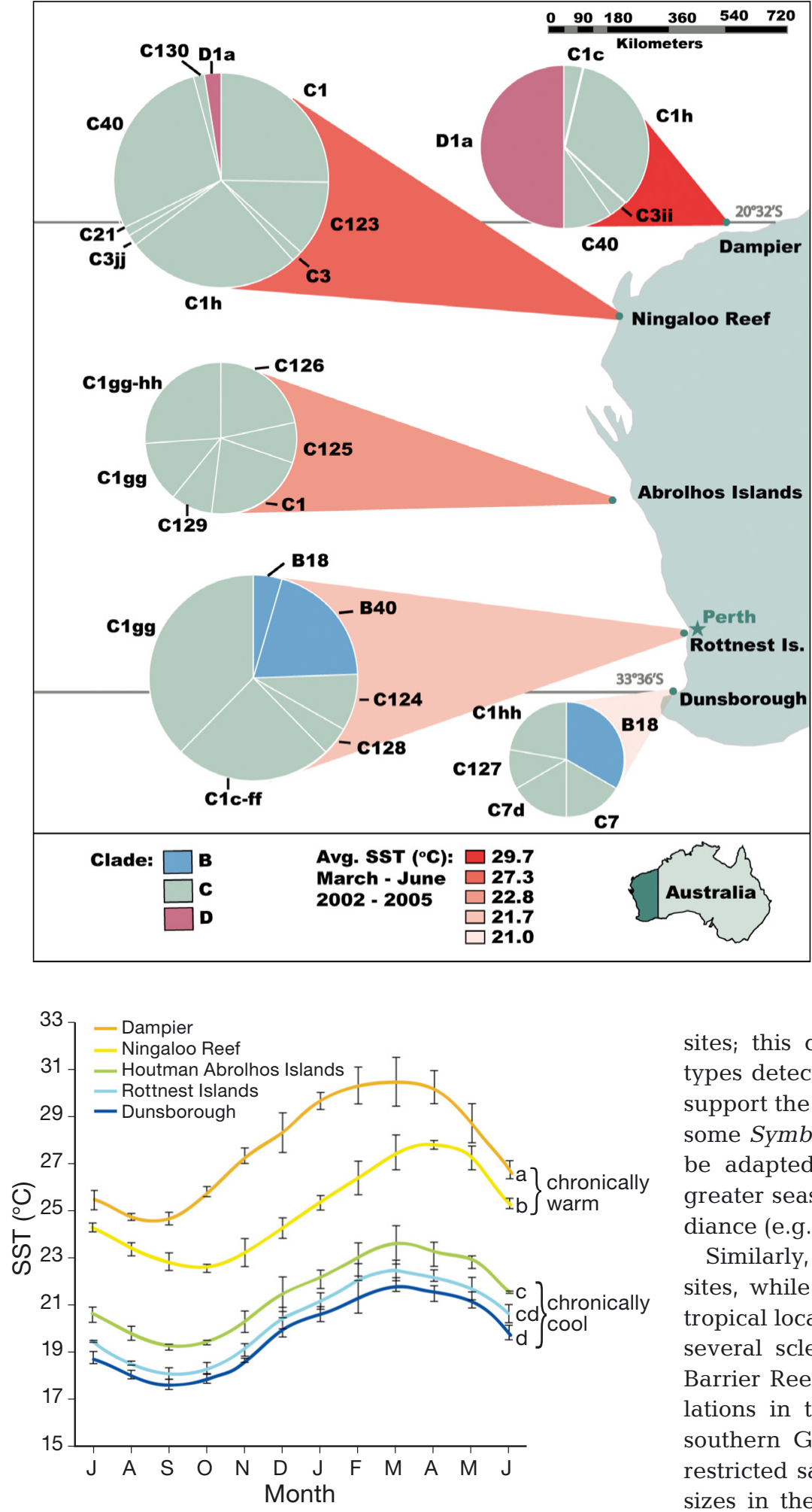

Fig. 4. Average monthly temperatures at 5 sites in Western Australia from 2002 to 2005. Sites with significantly different average monthly temperatures are indicated by 'a', 'b','cc','cd', and 'd' (1-way ANOVA, df = 4, p < 0.001 for all site comparisons except for the Abrolhos Islands vs. Dunsborough, where $\mathrm{p}<0.05)$. Error bars represent SD
Fig. 3. Observed distribution of Symbiodinium internal transcribed spacer-2 (ITS-2) types across a latitudinal gradient along the coast of Western Australia. Pie charts are scaled by area according to the number of samples analyzed: Dampier $(\mathrm{n}=27)$, Ningaloo Reef $(n=61)$, Abrolhos Islands $(n=23)$, Rottnest Island $(\mathrm{n}=45)$, Dunsborough ( $\mathrm{n}=$ 18). Total symbiont diversity detected from each sampled colony was scaled to equal one. For colonies hosting multiple types, each type was therefore scored as a fraction (e.g. for a colony hosting 2 types, each type was scored as 0.5). Color of pie wedge indicates Symbiodinium clade. Red-shaded cones correspond to the average March-June sea surface temperatures (SST) at each site from 2002 to 2005

tively, in temperate areas; however, we were unable to locate (and therefore, to sample) tropical conspecifics to determine whether Western Australian populations of these corals also experience a latitudinal transition in their symbioses. The $P$. versipora in temperate eastern Australia, however, appear to associate with a geographic variant of B18 (B18a), indicating that eastern and western populations of this coral associate with the same lineage of symbiont (A. C. Baker \& T. C. LaJeunesse unpubl. data). Samples collected in Dunsborough were also several meters deeper than at the other sites; this could have influenced the Symbiodinium types detected from this site. Our results nonetheless support the growing body of evidence suggesting that some Symbiodinium ITS-2 B types (e.g. B2) appear to be adapted to cooler temperate environments with greater seasonal fluctuations in temperature and irradiance (e.g. Thornhill et al. 2008).

Similarly, C7 and C7d were found only at temperate sites, while C40 appears to occur only in hosts from tropical locations. In previous studies, C40 occurred in several scleractinian genera from the central Great Barrier Reef (GBR), but was absent from coral populations in the cooler and more seasonably variable southern GBR (LaJeunesse et al. 2003, 2004a). The restricted sampling of coral diversity and low sample sizes in the present survey limit our ability to draw broad conclusions about the importance of temperature in restricting the range of these symbionts. Ideally, physiological examination would be required to understand the environmental tolerances of these symbiont types. 
A single clade D symbiont type, D1a, was detected (from colonies known to be capable of hosting Symbiodinium in clade D, see 'Materials and methods') with higher frequency at 'chronically warm' sites than at 'chronically cool' sites. This pattern was particularly pronounced in populations of Goniastrea aspera and Favites abdita; colonies of these species harbored D1a at significantly higher frequencies at Dampier than in the Abrolhos Islands. In contrast, Pocillopora damicornis did not show a high incidence of clade D symbionts at any of the sites examined. $P$. damicornis in this region does not appear to readily host symbionts in clade $\mathrm{D}$, as has been observed in other regions where conditions are highly turbid, extremely warm, and/or undergo wide seasonal fluctuations in temperature (e.g. Glynn et al. 2001, Baker et al. 2004, Correa 2009, LaJeunesse et al. 2010a,b). Between tropical and temperate sites, however, different $\mathrm{C}$ types dominated colonies of $P$. damicornis. The physiologies of these different types should be compared to determine whether they exhibit different temperature optima.

A growing body of evidence indicates that some symbionts in clade D can (1) increase the thermotolerance of some host taxa (Rowan 2004, Berkelmans \& van Oppen 2006, but see Abrego et al. 2008), and (2) become more abundant in coral populations after episodes of severe bleaching and mortality (Baker et al. 2004, Jones et al. 2008, LaJeunesse et al. 2009, $2010 b)$. Hosting these symbionts, however, likely represents a trade-off in terms of growth rate and/or reduced carbon uptake in juveniles (Little et al. 2004, Cantin et al. 2009) or other factors. Since moderate bleaching occurred in Dampier (but not in the Abrolhos Islands or the Ningaloo Reef) approximately 1 mo prior to sampling, this may have contributed to the higher relative abundance of Symbiodinium in clade D detected in Goniastrea aspera and Favites abdita sampled from Dampier reefs during May and June of 2005. Higher abundance of D1a may have resulted from (1) changes in symbiont communities as a result of severe physiological stress resulting in bleaching (e.g. Baker et al. 2004, Jones et al. 2008, LaJeunesse et al. 2009), (2) differential survival and/or reproduction (e.g. LaJeunesse et al. 2010b), or (3) both mechanisms. However, since individual colonies were not monitored through time during the present study, and non-bleached colonies were selectively sampled from Dampier, the mechanism(s) that contributed to the observed distribution patterns of ITS-2 type D1a cannot be teased out from the effects of chronically higher temperatures in the Dampier region compared to Ningaloo or the Abrolhos Islands. Further sampling of bleached and unbleached conspecific hosts in Dampier and Ningaloo before, during, and after bleaching events would improve our ability to tease out the potential effects of temperature and/or bleaching history on the abundance of Symbiodinium D1a.

\section{DGGE resolution of variation in the Symbiodinium ITS-2 region}

Although DGGE analysis of Symbiodinium ITS-2 rDNA has been suggested as a method for identifying Symbiodinium species (LaJeunesse 2005, Sampayo et al. 2008, 2009, Finney et al. 2010, LaJeunesse et al. 2010a), the ecological relevance of some Symbiodinium ITS-2 types has not been rigorously established (Correa \& Baker 2009). Regardless of whether some variation within the Symbiodinium ITS-2 is actually intra-specific (rather than species-level), it is widely agreed that the clade-level is too coarse for generalizations regarding the ecological and physiological attributes of Symbiodinium (Iglesias-Prieto \& Trench 1997a,b, Savage et al. 2002, LaJeunesse et al. 2003, 2004b, Iglesias-Prieto et al. 2004, Tchernov et al. 2004, Warner et al. 2006, Sampayo et al. 2007, 2008, Thornhill et al. 2008).

The multi-copy nature of the rDNA gene family and differences in rates of concerted evolution (Dover 1982) can produce symbiont individuals that share identical dominant sequences, but also possess distinctive co-dominant variants that increase the diversity and complexity of DGGE banding patterns associated with a single ITS-2 'type'. The high number of symbiont types closely related to $\mathrm{C} 1$ in the present study highlight the intragenomic variation and/or radiations present in the Symbiodinium of this region. While they are given distinct names that correspond to diagnostic DGGE profiles, the degree to which these intragenomic variants are distinct from one another at the species level is beyond the scope of the present study. Indeed, further verification with multiple markers as well as ecological observations would clarify the systematic implications of the variation detected here.

The Symbiodinium communities identified from Western Australian coral reefs corroborated previously observed clade-level biogeographic patterns, revealed 16 novel Symbiodinium ITS-2 types from clades B and $C$, and increased the total known diversity of coralSymbiodinium associations. In addition, a significant correlation between Symbiodinium in clade D and relatively warm and/or recently bleached sites was detected for multiple coral taxa, indicating that environmental history can influence symbiont dominance in some coral species. Given the variable environments, remote location, and novel symbiont diversity characterizing Western Australian reefs, future studies of this region have the potential to provide insights into how the coral-algal symbioses respond to environmental variation, climate change, and isolation by distance. 
Acknowledgements. We are indebted to T. Rouphael and D. Blakeway for help with logistics and coral collections. We also thank the Andrich Family for logistical support and housing in Western Australia, A. Kidd for assistance with fieldwork, H. Davie from Rottnest Island Authority, J. Prince at UWA for permitting support, C. J. Starger and H. H. Wirshing for molecular analysis support, A. Miller for help with figures, and R. K. Altman for his manuscript edits. R.N.S.'s travel and fieldwork was supported by Langmuir Scholars of Environmental Chemistry (Columbia University), Explorer's Club Youth Activity Fund Grant, Garden Club of America Summer Environmental Studies Fellowship, Thomas F. Dalton Memorial Scholarship in Undergraduate Environmental Sciences (Spill Control Association of America), and the Center for Environmental Conservation and Research (Columbia University). R.N.S. is supported by a University of Miami Graduate Student Fellowship and a National Science Foundation (NSF) Graduate Research Fellowship. A.M.S.C. was supported by a Graduate Research Fellowship from Columbia University. Travel costs for A.M.S.C. and all laboratory work were supported by grants from NSF (BIO-OCE 0099301 and 0547169) and the Lenfest Ocean Program (to A.C.B). Genetic analyses were partially funded by Penn State University and the NSF (IOB 544854 to T.C.L).

\section{LITERATURE CITED}

Abrego D, Ulstrup KE, Willis BL, van Oppen MJH (2008) Species-specific interactions between algal endosymbionts and coral hosts define their bleaching response to heat and light stress. Proc R Soc Lond B 275:2273-2282

Abrego D, van Oppen MJH, Willis BL (2009) Highly infectious symbiont dominates initial uptake in coral juveniles. Mol Ecol 18:3518-3531

Baker AC (1999) The symbiosis ecology of reef-building corals. PhD dissertation, University of Miami, Coral Gables, FL

Baker AC (2003) Flexibility and specificity in coral-algal symbiosis: diversity, ecology and biogeography of Symbiodinium. Annu Rev Ecol Evol Syst 34:661-689

Baker AC, Romanski AM (2007) Multiple symbiotic partnerships are common in scleractinian corals, but not in octocorals: comment on Goulet (2006). Mar Ecol Prog Ser 335: 237-242

Baker AC, Rowan R, Knowlton N (1997) Symbiosis ecology of two Caribbean acroporid corals. Proc 8th Int Coral Reef Symp, Panama 2:1295-1300

Baker AC, Starger CJ, McClanahan T, Glynn P (2004) Coral reefs: corals' adaptive response to climate change. Nature 430:741

Baker AC, Glynn PW, Riegl B (2008) Climate change and coral reef bleaching: an ecological assessment of longterm impacts, recovery trends and future outlook. Estuar Coast Shelf Sci 80:435-471

Berkelmans R (2002) Time-integrated thermal bleaching thresholds of reefs and their variation on the Great Barrier Reef. Mar Ecol Prog Ser 229:73-82

Berkelmans R, van Oppen MJH (2006) The role of zooxanthellae in the thermal tolerance of corals: a 'nugget of hope' for coral reefs in an era of climate change. Proc $\mathrm{R}$ Soc Lond B 273:2305-2312

Blackburn M (1942) A systematic list of the Hydroida of South Australia with a summary of their distribution in other seas. Trans R Soc S Aust 66:104-118

> Brown BE (1997) Coral bleaching: causes and consequences. Coral Reefs 16:S129-S138
Cantin NE, van Oppen MJH, Willis BL, Mieog JC, Negri AP (2009) Juvenile corals can acquire more carbon from high-performance algal symbionts. Coral Reefs 28: 405-414

Caputi N, Fletcher WJ, Pearce A, Chubb CF (1996) Effect of the Leeuwin Current on the recruitment of fish and invertebrates along the Western Australian coast. Mar Freshw Res 47:147-155

Chen CA, Yang YW, Wei NV, Tsai WS, Fang LS (2005) Symbiont diversity in scleractinian corals from tropical reefs and subtropical non-reef communities in Taiwan. Coral Reefs 24:11-22

> Clement M, Posada D, Crandall KA (2000) TCS: a computer program to estimate gene genealogies. Mol Ecol 9: 1657-1659

Coles SL, Jokiel PL, Lewis CR (1976) Thermal tolerance in tropical versus subtropical Pacific reef corals. Pac Sci 30: 159-166

Correa AMS (2009) Molecular ecology of endosymbiotic dinoflagellates (genus Symbiodinium) in scleractinian corals. PhD dissertation, Columbia University, New York, NY

> Correa AMS, Baker AC (2009) Understanding diversity in coral-algal symbiosis: a cluster-based approach to interpreting fine-scale genetic variation in the genus Symbiodinium. Coral Reefs 28:81-93

Correa AMS, Baker AC (2011) Disaster taxa in microbially mediated metazoans: how endosymbionts and environmental catastrophes influence the adaptive capacity of reef corals. Glob Change Biol 17:68-75

Cresswell G (1991) The Leeuwin Current: observations and recent models. J R Soc West Aust 74:1-14

> Cresswell GR, Golding TJ (1980) Observations of a southflowing current in the southeastern Indian Ocean. DeepSea Res A 27:449-466

Donner SD, Skirving WJ, Little CM, Oppenheimer M, HoeghGuldberg O (2005) Global assessment of coral bleaching and required rates of adaptation under climate change. Glob Change Biol 11:2251-2265

Dover G (1982) Molecular drive: a cohesive mode of species evolution. Nature 299:111-117

> Fabricius KE, Mieog JC, Colin PL, Idip D, van Oppen MJH (2004) Identity and diversity of coral endosymbionts (zooxanthellae) from three Palauan reefs with contrasting bleaching, temperature and shading histories. Mol Ecol 13: 2445-2458

Finney JC, Pettay DT, Sampayo EM, Warner ME, Oxenford HA, LaJeunesse TC (2010) The relative significance of host-habitat, depth, and geography on the ecology, endemism, and speciation of coral endosymbionts in the genus Symbiodinium. Microb Ecol 60:250-263

Glynn PW (1996) Coral reef bleaching: facts, hypotheses and implications. Glob Change Biol 2:495-509

Glynn PW, Maté JL, Baker AC, Calderón MO (2001) Coral bleaching and mortality in Panama and Ecuador during the 1997-1998 El Niño-Southern Oscillation event: spatial/ temporal patterns and comparisons with the 1982-1983 event. Bull Mar Sci 69:79-109

Goldberg J, Wilkinson C (2004) Global threats to coral reefs: coral bleaching, global climate change, disease, predator plagues, and invasive species. In: Wilkinson C (ed) Status of coral reefs of the world, Vol 1. Australian Institute of Marine Science, Townsville, p 67-92

Goreau TJ, Hayes RL (1994) Coral bleaching and ocean 'hot spots'. Ambio 23:176-180

> Goulet TL, Cook CB, Goulet D (2005) Effect of short-term exposure to elevated temperatures and light levels on photosynthesis of different host-symbiont combinations in 
the Aiptasia pallida Symbiodinium symbiosis. Limnol Oceanogr 50:1490-1498

Hall BG (2001) Phylogenetic trees made easy: a how-to manual. Sinauer Associates, Sunderland, MA

Hennige S, Suggett DJ, Warner ME, McDougall KE, Smith DJ (2009) Photobiology of Symbiodinium revisited: bio-physical and bio-optical signatures. Coral Reefs 28:179-195

Hoegh-Guldberg O (1999) Climate change, coral bleaching and the future of the world's coral reefs. Mar Freshw Res 50:839-866

Hoegh-Guldberg O, Mumby PJ, Hooten AJ, Steneck RS and others (2007) Coral reefs under rapid climate change and ocean acidification. Science 318:1737-1742

- Howells EJ, van Oppen MJH, Willis BL (2009) High genetic differentiation and cross-shelf patterns of genetic diversity among Great Barrier Reef populations of Symbiodinium. Coral Reefs 28:215-225

Hughes TP, Baird AH, Bellood DR, Card M and others (2003) Climate change, human impacts, and the resilience of coral reefs. Science 301:929-933

Iglesias-Prieto R, Trench RK (1997a) Acclimation and adaptation to irradiance in symbiotic dinoflagellates. II. Response of chlorophyll-protein complexes to different photon-flux densities. Mar Biol 130:23-33

Iglesias-Prieto R, Trench RK (1997b) Photoadaptation, photoacclimation and niche diversification in invertebrate-dinoflagellate symbiosis. Proc 8th Int Coral Reef Symp, Panama 2:1319-1324

Iglesias-Prieto R, Matta JL, Robins WA, Trench RK (1992) The photosynthetic response to elevated temperature in the symbiotic dinoflagellate Symbiodinium microadriaticum in culture. Proc Natl Acad Sci USA 89:10302-10305

Iglesias-Prieto R, Beltran VH, LaJeunesse TC, Reyes-Bonilla $H$, Thome PE (2004) Different algal symbionts explain the vertical distribution of dominant reef corals in the eastern Pacific. Proc Biol Sci 271:1757-1763

> Jokiel PL, Coles SL (1990) Response of Hawaiian and other Indo-Pacific reef corals to elevated sea temperatures. Coral Reefs 8:155-162

> Jones AM, Berkelmans R, van Oppen MJH, Mieog JC, Sinclair W (2008) A community change in the algal endosymbionts of a scleractinian coral following a natural bleaching event: field evidence of acclimatization. Proc Biol Sci 275:1359-1365

Kirk N, Andras J, Harvell C, Santos S, Coffroth M (2009) Population structure of Symbiodinium sp. associated with the common sea fan, Gorgonia ventalina, in the Florida Keys across distance, depth, and time. Mar Biol 156:1609-1623

LaJeunesse TC (2001) Investigating the biodiversity, ecology and phylogeny of endosymbiotic dinoflagellates in the genus Symbiodinium using the ITS region: in search of a 'species' level marker. J Phycol 37:866-880

> LaJeunesse TC (2002) Diversity and community structure of symbiotic dinoflagellates from Caribbean coral reefs. Mar Biol 141:387-400

LaJeunesse TC (2005) 'Species' radiations of symbiotic dinoflagellates in the Atlantic and Indo-Pacific since the Miocene-Pliocene transition. Mol Biol Evol 22:570-581

LaJeunesse TC, Trench RK (2000) The biogeography of two species of Symbiodinium (Freudenthal) inhabiting the intertidal anemone, Anthopleura elegantissima (Brandt). Biol Bull (Woods Hole) 199:126-134

LaJeunesse TC, Loh WKW, Woesik RV, Hoegh-Guldberg O, Schmidt GW, Fitt WK (2003) Low symbiont diversity in southern Great Barrier Reef corals, relative to those of the Caribbean. Limnol Oceanogr 48:2046-2054

LaJeunesse TC, Bhagooli R, Hidaka M, deVantier L and oth- ers (2004a) Closely related Symbiodinium spp. differ in relative dominance in coral reef host communities across environmental, latitudinal and biogeographic gradients. Mar Ecol Prog Ser 284:147-161

LaJeunesse TC, Thornhill D, Cox E, Stanton F, Fitt W, Schmidt G (2004b) High diversity and host specificity observed among symbiotic dinoflagellates in reef coral communities from Hawaii. Coral Reefs 23:596-603

LaJeunesse TC, Bonilla HR, Warner ME, Wills M, Schmidt GW, Fitt WK (2008) Specificity and stability in high latitude eastern Pacific coral-algal symbioses. Limnol Oceanogr 53: 719-727

> LaJeunesse TC, Smith RT, Finney J, Oxenford H (2009) Outbreak and persistence of opportunistic symbiotic dinoflagellates during the 2005 Caribbean mass coral 'bleaching' event. Proc Biol Sci 276:4139-4148

LaJeunesse TC, Pettay DT, Sampayo EM, Phogsuwan N and others (2010a) Long-standing environmental conditions, geographic isolation and host-symbiont specificity influence the relative ecological dominance and genetic diversification of coral endosymbionts in the genus Symbiodinium. J Biogeogr 37:785-800

> LaJeunesse TC, Smith R, Walther M, Pinzón J and others (2010b) Host-symbiont recombination versus natural selection in the response of coral-dinoflagellate symbioses to environmental disturbance. Proc Biol Sci 277:2925-2934

> Legeckis R, Cresswell GR (1981) Satellite observations of sea surface temperature fronts off the coast of western and southern Australia. Deep-Sea Res A 28:297-306

Little AF, van Oppen MJH, Willis BF (2004) Flexibility in algal endosymbioses shapes growth in reef corals. Science 304: 1492-1494

Loh WKW, Loi T, Carter D, Hoegh-Guldberg O (2001) Genetic variability of the symbiotic dinoflagellates from the wide ranging coral species Seriatopora hystrix and Acropora longicyathus in the Indo-West Pacific. Mar Ecol Prog Ser 222:97-107

- Macdonald AHH, Sampayo EM, Ridgway T, Schleyer MH (2008) Latitudinal symbiont zonation in Stylophora pistillata from southeast Africa. Mar Biol 154:209-217

> Magalon H, Baudry E, Husté A, Adjeroud M, Veuille M (2006) High genetic diversity of the symbiotic dinoflagellates in the coral Pocillopora meandrina from the South Pacific. Mar Biol 148:913-922

Markina NP (1976) Biogeographic regionisation of Australian waters of the Indian Ocean. Oceanology (Mosc) 15: 602-604

Marsh LM (1976) Western Australian Asteroidea since H.L. Clark. Proc 2nd Echinoderm Conf, Yugoslavia. Thalassia Jugosl 12:213-225

Maxwell JGH, Cresswell GR (1981) Dispersal of tropical marine fauna to the Great Australian Bight by the Leeuwin Current. Aust J Mar Freshw Res 32:493-500

McClanahan TR, Maina J, Moothien-Pillay R, Baker AC (2005) Effects of geography, taxa, water flow, and temperature variation on coral bleaching intensity in Mauritius. Mar Ecol Prog Ser 298:131-142

McClanahan TR, Ateweberhan M, Graham NAJ, Wilson SK, Sebastian CR, Guillaume MMM, Bruggemann JH (2007) Western Indian Ocean coral communities: bleaching responses and susceptibility to extinction. Mar Ecol Prog Ser 337:1-13

Mostafavi PG, Fatemi SMR, Shahhosseiny MH, Hoegh-Guldberg O, Loh WKW (2007) Predominance of clade D Symbiodinium in shallow-water reef-building corals off Kish and Larak Islands (Persian Gulf, Iran). Mar Biol 153:25-34 Muscatine L, Porter JW (1977) Reef corals - mutualistic sym- 
bioses adapted to nutrient-poor environments. BioScience 27:454-460

Pettay DT, LaJeunesse TC (2009) Microsatellite loci for assessing genetic diversity, dispersal and clonality of coral symbionts in 'stress-tolerant' clade D Symbiodinium. Mol Ecol Resour 9:1022-1025

Rodriguez-Lanetty M, Loh WKW, Carter D, Hoegh-Guldberg O (2001) Latitudinal variability in symbiont specificity within the widespread scleractinian coral Plesiastrea verispora. Mar Biol 138:1175-1181

Rodriguez-Lanetty M, Krupp DA, Weis VM (2004) Distinct ITS types of Symbiodinium in clade C correlate with cnidarian/dinoflagellate specificity during onset of symbiosis. Mar Ecol Prog Ser 275:97-102

Rowan R (2004) Coral bleaching: thermal adaptation in reef coral symbionts. Nature 430:742

Rowan R, Knowlton N, Baker A, Jara J (1997) Landscape ecology of algal symbionts creates variation in episodes of coral bleaching. Nature 388:265-269

Sampayo EM, Franceschinis L, Hoegh-Guldberg O (2007) Niche partitioning of closely related symbiotic dinoflagellates. Mol Ecol 16:3721-3733

Sampayo EM, Ridgway T, Bongaerts P, Hoegh-Guldberg O (2008) Bleaching susceptibility and mortality of corals are determined by fine-scale differences in symbiont type. Proc Natl Acad Sci USA 105:10444-10449

Sampayo EM, Dove S, LaJeunesse TC (2009) Cohesive molecular genetic data delineate species diversity in the dinoflagellate genus Symbiodinium. Mol Ecol 18:500-519

Santos SR, Shearer TL, Hannes AR, Coffroth MA (2004) Finescale diversity and specificity in the most prevalent lineage of symbiotic dinoflagellates (Symbiodinium, Dinophyceae) of the Caribbean. Mol Ecol 13:459-469

Savage AM, Goodson MS, Visram S, Trapido-Rosenthal H, Wiedenmann J, Douglas AE (2002) Molecular diversity of symbiotic algae at the latitudinal margins of their distribution: dinoflagellates of the genus Symbiodinium in corals and sea anemones. Mar Ecol Prog Ser 244:17-26

Seutin G, White BN, Boag PT (1991) Preservation of avian blood and tissue samples for DNA analyses. Can J Zool 69: 82-90

Strong AE, Barrientos CS, Duda C, Sapper J (1997) Improved satellite techniques for monitoring coral reef bleaching. Proc 8th Int Coral Reef Symp, Panama 2:1495-1498

Sunnucks P, Wilson ACC, Beheregaray LB, Zenger K, French J, Taylor AC (2000) SSCP is not so difficult: the application and utility of single-stranded conformation polymorphism in evolutionary biology and molecular ecology. Mol Ecol 9: 1699-1710

Editorial responsibility: Charles Birkeland,

Honolulu, Hawaii, USA
Tchernov D, Gorbunov MY, de Vargas C, Yadav SN, Milligan AJ, Häggblom M, Falkowski PG (2004) Membrane lipids of symbiotic algae are diagnostic of sensitivity to thermal bleaching in corals. Proc Natl Acad Sci USA 37: 13531-13535

> Thompson RORY (1987) Continental-shelf-scale model of the Leeuwin Current. J Mar Res 45:813-827

Thompson JD, Gibson T, Plewniak F, Jeanmougin F, Higgins D (1997) The ClustalX windows interface: flexible strategies for multiple sequence alignment aided by quality analysis tools. Nucleic Acids Res 25:4876-4882

Thornhill DJ, Kemp DW, Bruns BU, Fitt WK, Schmidt GW (2008) Correspondence between cold tolerance and temperate biogeography in a Western Atlantic Symbiodinium (Dinophyta) lineage. J Phycol 44:1126-1135

> van der Kaars S, De Deckker P (2003) Pollen distribution in marine surface sediments offshore Western Australia. Rev Palaeobot Palynol 124:113-129

van Oppen MJH, Palstra FP, Piquet AMT, Miller DJ (2001) Patterns of coral-dinoflagellate associations in Acropora: significance of local availability and physiology of Symbiodinium strains and host-symbiont selectivity. Proc R Soc Lond B 268:1759-1767

van Oppen MJH, Azita MJ, Done TJ (2005) Geographic distribution of zooxanthella types in three coral species on the Great Barrier Reef sampled after the 2002 bleaching event. Coral Reefs 24:482-487

Veron JEN (1995) Corals in space and time: biogeography and evolution of the Scleractinia. University of New South Wales Press, Sydney

Veron JEN (2000) Corals of the world, Vol 1-3. Australian Institute of Marine Science, Townsville

Veron JEN, Marsh LM (1988) Hermatypic corals of Western Australia. Rec West Aust Mus Suppl No. 29

Visram S, Douglas AE (2006) Molecular diversity of symbiotic algae (zooxanthellae) in scleractinian corals of Kenya. Coral Reefs 25:172-176

- Warner ME, Fitt WK, Schmidt GW (1999) Damage to photosystem II in symbiotic dinoflagellates: a determinant of coral bleaching. Proc Natl Acad Sci USA 96:8007-8012

> Warner ME, LaJeunesse TC, Robison JE, Thur RM (2006) The ecological distribution and comparative photobiology of symbiotic dinoflagellates from reef corals in Belize: potential implications for coral bleaching. Limnol Oceanogr 51: 1887-1897

Wijffels SE, Bray N, Hautala S, Meyers G, Morawitz WML (1996) The WOCE Indonesian Throughflow repeat hydrography sections: I10 and IR6. Int WOCE Newsl 24:25-28 http://woce.nodc.noaa.gov/wdiu/wocedocs/newsltr/

Submitted: September 17, 2009; Accepted: November 14, 2010 Proofs received from author(s): January 24, 2011 